\title{
AUDITIONS
}

\section{Elisabeth Schumann and Richard Specht: Strauss before Sixty}

Wayne Heisler Jr. and Laura Tunbridge

wheisler@tcnj.edu, laura.tunbridge@music.ox.ac.uk

Laura Tunbridge is Associate Professor in Music at the University of Oxford. She is author of [Robert] Schumann's Late Style (Cambridge, 2007) and The Song Cycle (Cambridge, 2010) and is now completing a book about Lieder singers in New York and London during the interwar period; related articles have appeared in the Journal of the American Musicological Society and Representations. She is currently editor of the Journal of the Royal Musical Association.

Wayne Heisler Jr., Associate Professor of Historical and Cultural Studies in Music at The College of New Jersey, is author of The Ballet Collaborations of Richard Strauss (Rochester, 2009). His recent research on music and dance has appeared in Dance Chronicle and the Journal of the American Musicological Society. Forthcoming are essays on ballets set to Strauss's Vier letzte Lieder in The Total Work of Art: Foundations, Articulations, Inspirations (Berghahn Books), as well as an essay on dancing to Mahler. Heisler's current book project concerns "songballets": modern and contemporary choreographies of Lieder and texted vocal music. 


\section{Introduction}

In the twenty-first century, the most widely known contemporary examination of Richard Strauss in the interwar years is Theodor W. Adorno's early essay "Richard Strauss at Sixty” (1924). ${ }^{1}$ Adorno saw Strauss as "nothing but surface” but that superficiality, in his Simmel-influenced reading, reflected the whole world: "an admittedly fragmentary reality of external things in the fruitless chase after that inner reality which is, by itself, quite unreal."2 As with many of Adorno's writings, his interpretation of Strauss was simultaneously of his time and at odds with it. The two texts excerpted here provide alternative, supplementary voices on Strauss from this period: soprano Elisabeth Schumann (1888-1952) and music journalist and musicologist Richard Specht (1870-1932). The vantage points and purposes of a young singer who soon would become a star of the age on the one hand, and an aesthete-musicologist on the other, are obviously very different from Adorno's. Still, just as Schumann's and Specht's contemporaneous accounts are enriched when placed alongside each other, they also illuminate Adorno: all three heard and witnessed the same Strauss, but understood and assessed what they observed differently.

Adorno did not broach Strauss as a performer, but much of Strauss's time after the First World War was spent directing, conducting, and accompanying. In 1921 Strauss embarked on a second tour of the United States (his first had been in 1904) with Elisabeth Schumann, among others. ${ }^{3}$ Schumann had sung Rosenkavalier's Sophie, in addition to other roles, to great acclaim at the Metropolitan Opera in the 1914-15 season, and was therefore known to American audiences. In May 1917 she also worked directly with Strauss in Switzerland, where he conducted her in Mozart's Don Giovanni and Zauberflöte (Schumann sang Zerlina and Papagena, respectively). ${ }^{4}$ This experience (and their resulting off-stage acquaintance) reportedly inspired Strauss to return to Lieder composition-he had largely abandoned the genre from 1906 until 1918 - and set the stage for Schumann's involvement in the 1921 American tour, as well as her engagement under Strauss at the Vienna State Opera. The excerpts of Schumann here are taken from the diary that she kept while travelling with the composer, available on the Elisabeth Schuman website as: "In Amerika mit Richard Strauss. Elisabeth Schumanns Tagebuch, 14. Oktober bis 31. Dezember 1921." ${ }^{5}$ Our excerpts slightly modify and annotate those translations that are available through the website. Schumann kept this diary for several reasons: for her husband, Karl Alwin, ${ }^{6}$ who could not join her for the trip; as an intimate personal record (for example, she notes when she is menstruating); and, lovingly, for posterity - in the final entry, written on the SS Olympic ${ }^{7}$ on 31 December 1921 as she was about to sail back to the Old World, Schumann characterized Strauss as a "great man," "wonderful friend," "like a father to his beloved daughter," and "the noblest of people." 8

Richard Specht was also a fervent admirer of Strauss, one might even say a sycophant. A poet and dramatist associated with the Jung-Wien circle, Specht is best known as a prolific music journalist, critic, and musicologist. His music publications include monographs on Mahler (1905, 1913), Johann Strauss II (1909), Wilhelm Furtwängler (1922), Brahms (1928), and Puccini (1931), and in 1925 he was appointed professor at Vienna’s Akademie für Musik und darstellende Kunst (a position that would have been terminated after the Anschluss had Specht lived to see it as he was Jewish). Here we offer excerpts from Specht's two-volume study Richard Strauss und sein Werk, written in Vienna between May 1917 and August 1920, published in 1921, and dedicated to the poet Arthur Schnitzler (about whom Specht subsequently penned a monograph). ${ }^{9}$ Although known internationally among Strauss scholars, Specht’s study 
has not been translated except in targeted quotations, and we include here a series of passages from volume one's first section, entitled “Der Künstler und sein Weg”(The Artist and His Path). ${ }^{10}$ Specht was acquainted with Strauss, who dedicated his sketchbook for Die Frau ohne Schatten to him, probably owing in part to Specht's laudatory guidebook to the opera (1919). Although Specht's and Adorno's philosophical and socio-political views could not be farther apart, both built on a hermeneutic methodology that mined personal and historical "truth" from music; for his part, Specht referred to Strauss’s oeuvre as his "Lebenslied” (life's song) and strove to derive from it a "Lebensbild" (life portrait), i.e., the music will tell you all you need to know. ${ }^{11}$ Specht's critical apparatus was unreliable-Romain Rolland categorized him among the "best dilettantes"12 — and he openly divulged that with his Strauss book he was "in the middle of the subject that is close to my heart" with the confession that "whatever in this book might be praised or criticized, one thing I know for certain: it is a book of love.”13

We have brought together our selected passages from Schumann and Specht into four categories: Strauss in/and America, Fandom and Political Display, Music in the Here-and-Now, and Strauss as Musician and the Contingencies of Performance.

\section{Strauss in/and America}

Elisabeth Schumman was overcome upon her arrival in New York City on the morning of 27 October 1921. Although it was not her first time in the United States, in the context of the World War One-era European ecomonic crisis, Manhattan's ostentatiousness could not have ceased to be astonishing. Schumann's treatment was particularly luxurious because she was part of Richard Strauss's celebrity entourage. Given Strauss's reputation for materialism, his grand American reception seems fitting. Richard Specht generally understood Strauss's character to be "thoroughly Bavarian," refined by the culture of a "good European."14 Nevertheless, Specht saw an affinity between Strauss and America, with the latter representing marketplace logic. Specht's intriguing description of Strauss as "smack[ing] of something American” was, however, a partially rhetorical attempt to rescue the composer from his reputation for avariciousness. Predictably incompatible with Adorno, for whom Strauss and his music were all appearance, Specht had faith in the integrity of the man beyond the façade. Still, he seems to have been at pains to reconcile the "real” Strauss he admired so much with the composer's outer life.

Schumann, 27 October 1921, 11 o’clock in the evening: “In New York for two hours. Arrival with all the brightly lit skyscrapers absolutely fantastic_overwhelming impression. I am beginning to feel well and to enjoy the journey. New York is the grandest thing in the world - if only $\mathrm{Ce}^{15}$ could experience all this with me! [Tour manager] Diamond came on board-then twenty reporters and photographers rushed towards us like wild animals - yes, we were even filmed - that doesn't happen every day. And tomorrow we get to see everything. We are staying in the Hotel St Regis 5th Avenue, ${ }^{16}$ have a charming suite with a lounge, two bedrooms, two bathrooms, and little dressing rooms. The most beautiful roses are resplendent in American quantities on all the little tables-Strauss has lots of friends here-only a wonderful giant bouquet is from the hotel. They've even put a grand piano into the room. In my bathroom there are about a dozen hand towels, three large bath towels - by the basin and bath there is soap with the name of the hotel written on it. I feel as if I'm in paradise. Incidentally, we're on the 17th 
floor. On Monday there's to be a huge reception for Strauss with the Mayor, etc. Tomorrow more-I can’t keep my eyes open." ${ }^{17}$

Specht: "[Strauss] is not, by the way, completely innocent of the scandalous and erroneous tale of 'Salesman Strauss.' Because one thing must be acknowledged: that the entire outward life, as it has developed for and around Strauss, smacks of something American and a bit too much of 'business,' and that one cannot totally separate the material from the artistic — that is: from reproduction [Reproduktivkünstlerischen]. ${ }^{18}$ All the more commendable, that precisely with the already purely physical admirable output Strauss accomplishes, be it in Berlin and Vienna, be it on continuous travels, and with the conversion of the artistic into cash value based on this, his creation remains completely unspoiled by it, ruthlessly unconcerned with what others expect from him, totally turned away from the desire of the 'shopkeeper.' ${ }^{19}$ But all the same, there are still instances in which he was not able to maintain purely the total and sacrosanct conviction of his artistic conscience. Once, when he offered his customary artistic resources to conduct the 'infamous' concert at Wannemaker's department store in New York, ${ }^{20}$ to the approval of the satisfied audience, he spoke these calm, proud words against fatuous attacks on the concert: 'True art ennobles any room, and respectable fundraising for wife and child does not harm anyone, not even an artist.' Nowadays there are instances, however, in which he should at least tone down this declaration; when he, who could have easily done without this or that honorarium, might have turned down a concert or theater performance (for example, in 1917 in Switzerland), ${ }^{21}$ also if the preconditions of the artistic or, more precisely, the Straussian standards were not completely met, or after all in the eleventh hour through cancellations or other hindrances in such a way was belittled, that he refused to conduct, to take responsibility for the whole thing, and to cover up for it with his name. That he sometimes does just that, be it out of a certain foolish confidence in victory, which is taken for granted, be it out of some contempt for the public, but finally in a fit of insufficient reverence for the work of art, he, who is otherwise the most matterof-fact of all artists, is treated with great suspicion. (Even then not unjustly, if in the end the affair goes wholly or in part without a hitch. Which, by the way, was not always the case.) Occurrences such as these, which in the productive and enriching life of this bountiful artist are rare and isolated, would hardly be worth mentioning if they were not-grossly exaggerated and maliciously generalized - the main provocation for that scurrilous tale of a cynical and money-hungry Strauss. But the fact that he, in the sense just mentioned as well as others previously discussed, is not totally without a share in this misconception of his nature, formulated out of spite and stupidity, may not be concealed in an account such as this, which without truthfulness would be worthless." 22

\section{Fandom and Political Display}

For all of their differences, Schumann's and Specht's portraits of Strauss are quite consonant: the composer emerges as a conquerer, a hero even. For Schumann, Strauss transcended celebrity as something of a cultural monarch, and specifically an icon of German Kultur, thus giving a sense of how strong German-American cultural allegiances remained despite war-time political hostilities. ${ }^{23}$ Specht's Strauss is nothing less than a champion of the human spirit; again, Specht exerts considerable effort to distinguish between the public Strauss and the inner person. As 
always, such symbolic politicization dwarfs human actors, although Strauss's seemingly humble embarrassment by the spectacle surrounding his arrival ceremony apparently subsided by the time he discussed “composing endings” over a midnight snack. Specht's hope that Strauss's music might convert the rabble proves to be in vain given Schumann's report from middle America that the press had exchanged Richard Strauss for Johann Strauss II. (Unlike Schumann, Adorno would probably have found this mix-up to be canny and not at all humorous.)

Schumann, 31 October 1921: “At noon a huge reception for Strauss given by the Mayor of New York. ${ }^{24}$ About fifteen cars were pulled up in front of the Hotel St. Regis_-all bearing the municipal arms at the back. In the first one Strauss was driven with three gentlemen, in the second Franz ${ }^{25}$ with an escort, in the third me with [tour manager] Diamond, in the fourth Dux ${ }^{26}$ _ I didn't know the other people. There was a police convoy flanking the cars to left and right on motorbikes with sirens on the whole time; that meant that we crossed every road without having to stop, all other cars had to stopto the left and right there were people lining the streets - of course they had all read about the reception. Strauss travelled through New York City like a king. The front of City Hall was teeming with photographers - we were filmed and photographed. Then we went into City Hall. Lots of invited guests were already waiting in the great hall. First of all a nephew of Goldmark ${ }^{27}$ spoke, then Mr. Berlitzheim [sic], ${ }^{28}$ then the Mayor. Strauss stood up and responded — at first very haltingly — then fluently and full of wit. He spoke in German and apologized for speaking in his mother tongue. But his short speech was translated into English and immediately afterwards read out, whereupon there was tremendous applause. Strauss was moved by the great honor-he looked quite pale. Then there was a big introduction ceremony, in which Dux and I were introduced to the Mayor. After that lots of filming again and departure to the hotel, where Diamond gave a breakfast. In the evening the big occasion of Strauss's concert in the Carnegie Hall, which was like a victor's triumph-afterwards we three sat up in our hotel room and had a midnight snack. He [Strauss] said, among other things, 'It is difficult composing endings. Beethoven and Wagner could do it. Only great composers can do it. I can do it, too.",29

Specht: "Whether the Master Strauss's public will also be the public for this book I do not know. But I would hope so; if nothing else, because those are the readers I would like to capture. In contrast, Hermann Bahr once spoke about this public in words that are amusing and unfortunately true: 'Tell me who you like and I will tell you who you are! One knows the artist through his admirers. That is almost always the case. But not Richard Strauss, not at all. The scum of Europe throngs to his premieres; there one finds assembled the worst society, one longs for an unconcealed pickpocket. Hence his [Strauss's] world fame. But if one then looks him in the eyes it is not comprehensible. And even less so if one just listens to his music. His music must horrify these admirers. He is lucky that they do not listen to it. What they admire and extol in him is his athletic ability. ${ }^{30}$ That is exaggerated only insofar as, next to this [low] society, the ten or twenty best people from Europe are there as well when a new Strauss work is performed. But otherwise it is only too true. The enormous success of Strauss's music is as much a misunderstanding as that - in the master's own sad statement-of Wagner's was. From this misunderstanding I would like to help to bring about understanding: that also the 
snobs, Mr. and Mrs. To-Be-Found-Everywhere, the fools, the ordinary people, the mere intermediaries of art, can learn to hear it. Really hear - as it is, not as it seems to them. Because then most of them would be driven away in horror and only a few of them, in whom, behind their vanity and curiosity, some sort of yearning, a furtive wish for some meaning in their empty lives lies dormant_-for that meaning that Richard Strauss's music, this victory march of the fleshly, carries glowingly in itself like no other todaythese few would suddenly be awakened and discover that they have become other, more free, self-assured people.”31

Schumann, 21 November 1921: “Arrived in St. Louis at 5 o'clock-great success, in good voice. Had dinner afterwards with Piastro and his charming wife. ${ }^{32}$ Both of them are staying here until the 26th [of November], when the three of us leave for Indianapolis. Am so glad not to be here alone as Strauss and Taylor ${ }^{33}$ are travelling to Kansas City tonight where he's doing a concert with Dux. Strauss really wanted to bring me along, but I want a bit of peace - ten hours' train journey there and back—no, I'd rather stay here even if I am all alone.” 23 and 24 November, 1921: [23 November:] "Dreadful loneliness. Went for a walk in the park with the Piastros in the afternoon-went to bed early. [24 November:] This morning was in the park all alone for an hour and a half. Lovely cold day after the thunderstorm in the night, which quite frightened me. Oh, if only I could sing and travel every day so that I didn’t have to experience a town like this for longer than necessary. By the way, I forgot to mention that on Strauss's arrival here all the newspapers were full: 'The Waltz King is here.' And there was a photo of the statue of Johann Strauss (in Vienna's Volksgarten). ${ }^{34}$ That's typical of this town, but at least it's funny.”35

\section{Music in the Here-and-Now}

Schumann does not consistently provide factual data about performances in her account, e.g., song titles, venues, fellow performers. She does, however, offer fascinating details about her social and personal experiences, including the role that Strauss served as an artistic mentor. Schumann's quotations reveal a rather unshackled composer and are complemented by Specht's emphasis on Strauss's foundational investment in the effect of sound: the printed notes were only prescriptive to a point, serving as the means to non-exhaustive ends. "With the courage for melody whose sources often flow north from Italy": this and other descriptors employed by Specht throughout his study ${ }^{36}$ closely align Strauss with Nietzsche and distance him from the German Romantics to an extent that was by no means universal in the interwar period. (This understanding of Strauss is now commonplace in musicological treatments.) Specht is only a breath away from naming Strauss’s Bergsonian élan vital, which, in stark contrast to Adorno’s assessment (and Mahler's grapplings), empowers audiences to be like him and stare down ineffable truths. ${ }^{37}$

Schumann, 25 October 1921: "Charity concert for the widows and orphans of sailorshad great success with three Strauss songs. Chaliapin ${ }^{38}$ also sang: wonderful artist, unfortunately not quite in top form any more. Then a lady played a violin sonata by Strauss, too. Strauss is so delightful and always intent on my success. Before the concert he said: 'Why not hold your top notes a little longer, don't always sing so precisely.' 
Afterwards I asked him: 'Well, did I sing the top notes long enough?'- 'Yes,' he said gaily, 'but always with a bit of a guilty conscience.' He means because I always sing what's written. He beamed at my success. Afterwards we all sat cozily in the smoking room for a while."39

Specht: "Richard Strauss: the strongest force propelling the compass needle of contemporary music; the antithesis of Max Reger, who is in love with old forms and fills them with his music, which itself is determined by those forms, while Strauss is in love with expressive capabilities, bringing to life in sound the visions that inhabit his mind, and which determine the form. The redeemer of pathos, of the Adagio enunciation at all costs; the conqueror of new territories in music, with the courage for extremes in all daring of intensified and sophisticated rhythm and harmony, and with the courage for melody whose sources often flow north from Italy and that nevertheless, where its powerful radiance becomes sweetly quivering sentimentality, reveals a hidden lightheartedness, almost parodistically rescued by ironically exaggerated yearning, as to betray a softness, precisely that which perfectly befits this valiantly upright, adventurous, unshakable, and cheerfully composed humanity. The most convincing evidence that law and rule must not become shackles, but rather become factors of organic development, if one who is able comes to what he does not desire to use, he may spurn what has already been said a hundred times and rely on his own mastery, which fortifies the untested, keeps everything arbitrary at bay, and makes accessible to everyone the content for a bright today, all dreams of a better tomorrow. ... He belongs among the very few about whom one cannot avoid debate; who one may regard with hate or joy, with repulsion or admiration, but on whom one must take a position; those who are not to be ignored and to whom no one can remain indifferent. And to those who always have new surprises; who are not to be tied down to a certain past; who one always finds where they are least expected, and who mock every fixed formula and every established category [Registrierung]. That is what they have often held against him; that he never concerns himself with wishes and prophecies, but rather only with his innermost precepts and the needs of the moment, with the drive-frequently defying his own powers of judgmentof the dictatorial voice that summoned him to creation. He was always so and is still so today. When he takes a rest after completing a work, it is a holiday without a break; not a target point, only a milestone; a short way station, but already with a view towards new expanses." 40

Schumann, 2 November 1921: "Journeyed back with Strauss [from Philadelphia to New York City] in the morning. We talked about voices and studying. I asked him if he thought I could learn something from Sembrich. ${ }^{41}$ He said no and 'any improvements you need to make I can tell you, or your husband. You ought to sing more legato and learn, for example, how to do with your facial expression what your voice can't manage. You often sing too honestly_hide your weaknesses by cheating a little.' He is right.”42

Specht: “The more often one meets Strauss's works, the more understandable they become, all terror disappears-even Elektra with its dark, dreadful greatness speaks in grandiose voices of bronzed melody, where most people earlier believed to hear only incoherent, concentrated tone-cascades of roaring dissonances; at first one understood 
only the gesture, only the bewitching brilliance of the attitude, but only later the tonal language itself, which is thoroughly contemporary and nevertheless takes up fully the natural development of things; and only some come to love this tonal language as the highest, most powerful, life-affirming, earthly expression of ourselves and our epoch, in contrast to Mahler's music, escapist, searching for the beyond, heaven-exalting, which transports us from this world, while above all Strauss's music leads us into it, heightening all powers, all zest for life. ... [Strauss] seldom goes down into the depths, but leads with marvelous verve into the heights and to the summit. He does not solve the mysteries of life; but he arms us for such understanding. In contrast to many a music, which is 'not of this world,' his music is — at least almost always - totally of this world, totally of this life." 43

\section{Strauss as Musician and the Contingencies of Performance}

Through her recounting of two performances on their tour (Pittsburgh, Detroit) with all of their logistical challenges and musical revelations, Schumann portrayed the "other" Strauss: the performer-musician who composes (extemporaneously, even, for better or worse), a refreshing counterpart to Strauss the German composer in the wake of Wagner that Specht could not resist. (The notion of Strauss's composing as a something of a performance was also evidenced by his contemporary reputation for “orchestral virtuosity,” which Adorno believed was apt.) As with Schumann's previous account of the performance liberties advocated by Strauss, her specific examples here resonate with written and recorded documents of conductor-Strauss's operatic and symphonic performance practices, and bear remembering when approaching his scores. Specht emphasizes their interpretive difficulty and, despite his pseudo-complaint that Strauss privileged his own works, saw great promise in Strauss's fostering of German musical Bildung though the model of his music. ${ }^{44}$ Strauss's Wagnerian legacy, then, would be at the Vienna Opera- a new Festspielhaus — where he was co-director (with Franz Schalk) from 1919-1924.

Schumann, 9 November 1921: "Pittsburgh, terrible rain-impossible to put a foot outside. Dreadful boredom. Concert great success - audience not as warm as in Chicago. Strauss said, 'You sing much too beautifully for these people.' Had to repeat 'Wiegenlied' and 'Schlechtes Wetter.' The music was missing for the last number, 'All mein Gedanken’. Strauss said: 'I know it by heart'. But he played such a hotchpotch of notes that I can't think how I managed to stay in the right key. Otherwise I was very calm and I wasn't even tired afterwards-I've worked out how to sing at half strength. We sang 'Ständchen' as an encore. After the concert, immediately into the sleeping car where I am now writing - the train hasn't left yet but is about to." 45

Specht: "From conductor-Strauss I have heard almost exclusively interpretations of his own works; only in a few concerts of the Berlin Court Orchestra and the Vienna Philharmonic, and most recently at the Vienna Opera, has he been for me the vessel of compositions by other masters: Beethoven, Mozart, Wagner, Bruckner. ... Indeed, apart from his regular concerts and opera performances, he conducts almost exclusively music by Richard Strauss. Which not only means an unfailing celebration of new revelations and passion-filled, lively hours, but even bears in itself definite importance; for the discovery of the proper performance of this music, for clearing away all of the debris that 
incompetence and uncomprehending stupidity have piled up regarding these works to the point of them being unrecognizable, for the training of the true style of Strauss interpretation, which is admittedly still in its infancy and will only be achieved when singers and instrumentalists not only perform the correct notes in the correct tempo (which is already a lot!), but when the spirit and meaning and the formal coherence become apparent to them, when they understand the nature of the melody, while for the time being most of them perceive only more or less difficult intervals but not the arch of the unified melodic line, and when every convulsiveness and mechanical bondage secedes. What Richard Strauss achieves in all of the large German cities, not only on behalf of his own works but as orchestra and singer pedagogue, as awakener to new purposes as well as to the highest conscientiousness and discipline- this extensive qualitative and quantitative power was previously mentioned. But there is no doubt that he has already committed himself with equal vigor to advocate for all lofty examples of musical art and to be a praeceptor germaniae of music; provided that it could happen in the dignified and high-spirited manner that is expected by him. Then Wagner's concept of the "style-training school" [Stilbildungsschule], ${ }^{46}$ which in his time failed ignominiously due to the indifference of his contemporaries, would become a reality. And perhaps now at least a part of it will be realized if Strauss, as director of the Vienna Opera, offers up art. It is difficult to believe that what happened then, to the disgrace of that musical generation, could also happen nowadays: that if Strauss appeals to such training, as Wagner once did, this call of a master, who offers to be a mentor to all who want it, without any other compensation except for the pleasure afforded by work and progress, could be lost in the void. No one came to Wagner as a disciple. It is hard to believe that now, after thirty years of Bayreuth, the situation could be no different. But nothing is impossible." 47

Schumann, 7 December 1921, Detroit: “Arrived 9 o’clock in the morning. Unlucky day. Trunk not arrived. Had to buy dress, shoes, stockings, while the manager rushed around trying to find music. He only got hold of some of it and we had to add Schubert to the programme. Strauss, as always, completely calm. Thank God, because I was a bit nervous. Nevertheless, in good voice in the evening - great success. I announced each song individually, which the audience particularly liked. Schubert songs: 'Musensohn,' 'Frühlingstraum,' 'Forelle,' 'Geheimes,' and 'Lied im Grünen.' We had managed to get various Strauss songs, and Strauss played some from memory. He's not a good by-heart player, and something extraordinary happened in 'All mein Gedanken.' Already after the third bar he couldn't remember the accompaniment anymore and composed an entirely new song. I leapt along with him, the words fitted perfectly, no one in the audience suspected a thing, and when we luckily had made it to the end I turned my eyes to the right to see what his reaction was. All I saw was him grinning from ear to ear-it was really difficult for me to find the calm and seriousness needed for the next song, 'Freundliche Vision.' After the set we couldn't stop laughing in the artists' room, and I asked him straightaway afterwards to write down the new 'All mein Gedanken,' but he replied. 'Oh, I've already completely forgotten it.' What a pity! I liked it much more than the original." 48 
Assumedly, Strauss was "grinning from ear to ear” because he had pulled one over on the public, which supports the portrait of him as a musician who reveled in facades. At the same time, the impression that Schumann was quite taken by the new "All mein Gedanken” might suggest that it was an authentic moment, one in which the truth of Strauss's character-his untruth, for Adorno—shone through. Like most musical experiences, the allure of this improvised song was amplified by its evaporation. What Schumann and Specht were able to value in Strauss was his acute awareness and embrace of the contingencies of modern life and musical performance, as well as Strauss's alignment with one view of music's shaky ontology — a view that was alien to Adorno. For both Schumann and Specht, Strauss's musical works worked on them; and although the composer may not emerge as any less flippant or avaricious, reading Schumann and Specht in conjunction with each other provides context to understand more deeply these often overlooked aspects of Strauss from a seemingly marginal period, ultimately supplementing the dominant Adornian narrative.

\footnotetext{
${ }^{1}$ Theodor W. Adorno, "Richard Strauss. Zum 60. Geburtstag: 11. Juni 1924,” Zeitschrift für Musik 91 (1924): 28995; translated by Susan Gillespie as "Richard Strauss at Sixty," in Richard Strauss and His World, ed. Bryan Gilliam (Princeton: Princeton University Press, 1992): 406-15. Adorno's much later, more developed take on Strauss, "Richard Strauss: Zum hundertsten Geburtstag, 11. Juni 1964," originally appeared in Neue Rundschau 75/4 (1964) and was translated in two parts by Samuel and Shierry Weber as "Richard Strauss: Born June 11, 1864," in Perspectives of New Music 4, no. 1 (Autumn-Winter 1965): 14-32, and 4, no. 2 (Spring-Summer 1966): 113-29. ${ }^{2}$ Adorno, "Richard Strauss at Sixty," 409.

${ }^{3}$ The 1921 tour was arranged in part so that Strauss could recoup funds as his savings, largely deposited in English banks, had been confiscated during the war. On his earlier 1904 American tour, see Linda L. Tyler, "'Commerce and Poetry Hand in Hand': Music in American Department Stores, 1880-1930," Journal of the American Musicological Society 45, No. 1 (Spring 1992), 75-120.

${ }^{4}$ On Strauss's 1917 Switzerland performances, see Michael Kennedy, Richard Strauss: Man, Musician, Enigma (New York: Cambridge University Press, 1999), 196-99; and Chris Walton, Othmar Schoeck: Life and Works (Rochester, NY: University of Rochester Press, 2009), 69-70.

${ }^{5} \mathrm{http}: / /$ www.elisabethschumann.org/1921diary.htm, accessed 13 June 2015. We are grateful to Elisabeth Schumann's granddaughter Joy Puritz for allowing us to reproduce passages from the diary, including her original English translations, as well as her expert proofreading of our manuscript.

${ }^{6}$ Conductor Alwin Oskar Pinkus (1891-1945), who changed his name to Karl (or Carl) Alwin. He was Schumann's second husband from 1919-1933. Following the Anschluss in 1938, he emigrated from Vienna to Chicago and then Mexico City.

${ }^{7}$ The Olympic was a sister ship to the Titanic and Britannic ocean liners; while the latter two famously sank (in 1912 and 1916, respectively), the Olympic continued to make Atlantic crossings until 1934.

8 "Ich lasse noch einmal die ganze Zeit an mir vorüber ziehen, und Dir, Du großer Mann, Dir Richard Strauß, gedenke ich gerührten Herzens und danke Dir mit aller Innigkeit, die mir zu Gebote steht. Du warst mir ein wundervoller Freund - an Deiner Seite war ich geschützt gegen alle Intriguen und Managergemeinheiten. Du warst immer nur auf meinen Erfolg bedacht, warst um meine Gesundheit besorgt und brachtest mir Medikamente, wie ein Vater seiner geliebten Tochter. Ich habe Dich als einen der edelsten Menschen kennen gelernt, der für Wahrheit und Ehrlichkeit seine ganze Persönlichkeit einsetzt. Es war eine herrliche Zeit, diese 2⿺辶⿸厃㔾 Monate, täglich, ja stündlich an Deiner Seite zu sein. Du giebst einem immer, selbst wenn Du schweigst. Mein ganzes Leben lang bin ich Dir verpflichtet—Du wirst es erleben, daß ich dankbar bin und es Dir nie vergesse!” Schumann, 31 December 1921.

${ }^{9}$ Richard Specht, Richard Strauss und sein Werk, 2 vols. (Leipzig: E. P. Tal, 1921).

${ }^{10}$ We are grateful to Anna Kampen and Gundula Kreuzer for their feedback and recommendations regarding our translation of Specht.

${ }^{11}$ See Specht I, 13.

${ }^{12}$ Diary entry of 12 May 1924, in Richard Strauss and Romain Rolland, Correspondence, Together with Fragments from the Diary of Romain Rolland and Other Essays, ed. and trans. Rollo Myers (Berkeley and Los Angeles: University of California Press, 1968), 165.
} 
13 "Ich stehe mitten in der Sache, die mir am Herzen liegt”; "was immer an diesem Buch gelobt oder getadelt werden mag, eines weiß ich gewiß: es ist ein Buch der Liebe.” Specht I, 12 and 17, respectively.

14 "Das alles ist nicht münchnerisch; aber gut bajuvarisch ist seine ganze Erscheinung in ihrer blendenden Gesundheit, ihrer rotblütigen, schalkhaften Heiterkeit, ihrem guten Zorn, ihrer festen, ruhigen, besonnenen Kraft, ihrer einfachen, herzlichen Kindlichkeit, ihrer prangenden Sinnlichkeit und ihrem jäh aufstürmenden Temperament. Das sind die Grundfarben; aber sie sind unendlich differenziert durch die Kultur eines 'guten Europäers', durch die Bravouren und Finessen eines geschmeidigen, fechterischen Geistes, vor dem die Seele seiner Zeit keine Geheimnisse und der zu allem Lebendigen unserer Tage Beziehung und Verhältnis gefunden hat.” Specht I, 28. ${ }^{15}$ Again, Schumann's husband Karl (or Carl) Alwin.

${ }^{16}$ Built by John Jacob Astor IV (of Waldorf-Astoria fame) and opened in 1904, the Hotel St. Regis (now "The St. Regis New York") is located at 2 East $55^{\text {th }}$ Street (between $5^{\text {th }}$ and Madison avenues).

17 "Zwei Stunden in New York. Hinfahrt mit all den erleuchteten Wolkenkratzern einfach phantastischüberwältigender Eindruck. Ich fange an mich wohl zu fühlen und die Reise zu genießen. N.Y. ist das großzügigste was es überhaupt giebt—wenn Ce doch alles miterleben könnte! Diamond kam auf 's Schiff—dann stürzten 20 Reporter und Photographen auf uns zu wie die wilden Tiere— ja, wir wurden sogar gefilmt—-das giebt's nur einmal in der Welt. Und morgen ist schon alles zu sehen. Wir wohnen im Hotel St. Regis 5th Av., haben ein entzückendes Apartement mit einem Salon, 2 Schlafzimmern, 2 Badezimmern und kl. Garderoben. Die schönsten Rosen in amerikanischen Mengen prangen auf allen kl. Tischen—Strauß hat ja viele Freunde hier—nur ein wunderbares Riesenbouquet ist vom Hotel. Sogar einen Flügel hat man uns in’s Zimmer gestellt. In m. Badezimmer hängen ungefähr 1 Dtz. Handtücher, 3 große Badetücher —am Waschtisch und Wanne liegt Seife mit der Inschrift des Hotels. Ich komme mir vor wie im Schlaraffenland. Wir wohnen übrigens 16. Stck. Montag soll ein gr. Empfang für Strauß sein mit Begrüßung des Bürgermeisters u.s.w. Morgen mehr-meine Augen fallen zu.” Schumann, 27 October 1921.

18 "Reproduktivkünstlerischen" as "reproduction” in Adorno's sense of performance as recreative (vs. composition as a productive process). We are grateful to Gundula Kreuzer for this point.

${ }^{19}$ Specht’s quotation of “Händler” (shopkeeper) is probably referencing Strauss’s recent satirical Lieder cycle Krämerspiegel (Op. 66, 1918). Although Specht frankly admits that, "Den 'Krämerspiegel' ... kenne ich noch nicht," he goes on to indicate general familiarity with these songs: "[Krämerspiegel] ist vorläufig von den großen Firmenherren abgelehnt worden—was immerhin einen neuen Beleg seines Inhalts bedeutet.” Specht II, 32.

${ }^{20}$ Strauss conducted two concerts at Wanamaker's department store in Manhattan during his 1904 North American tour, including his then-new Symphonia domestica, which had been premiered at Carnegie Hall on the same tour. For an overview of the scandal these concerts unleashed, see Bryan Gilliam, The Life of Richard Strauss (New York: Cambridge University Press, 1999), 81-82; see also Tyler, “'Commerce and Poetry Hand in Hand’: Music in American Department Stores, 1880-1930.”

${ }^{21}$ In January and February of 1917, Strauss conducted the orchestra of the Mannhein Court Theater in performances of Elektra and Ariadne auf Naxos (1916 version) on tour in Switzerland, and also conducted the Tonhalle Orchestra in concerts of his Burleske for piano and orchestra, Also sprach Zarathustra, and Don Quixote. Tickets for the Switzerland concerts were notoriously expensive. The only apparent circumstances that might have led Strauss to turn down any of these performances (which he did not) was the slow tempo to which Wilhelm Furtwängler's Mannheim ensemble was accumstomed; see Strauss, letter of 7 February 1917 to Hofmannsthal, in Strauss and Hofmannsthal, A Working Friendship: The Correspondence between Richard Strauss and Hugo von Hofmannsthal, trans. Hanns Hammelmann and Ewald Osers (New York: Random House, 1961), 265-66. As discussed in our introduction, Strauss returned to Switzerland in May 1917 to conduct Mozart with Schumann in the casts.

22 “Ganz und gar schuldlos an der empörenden und falschen Legende vom 'Kaufmann Strauß' ist er übrigens nicht. Denn eines wird zugegeben werden müssen: daß dem ganzen äußeren Leben, wie es sich für Strauß und um ihn herum gestaltet hat, etwas Amerikanisches und ein wenig viel vom 'Betrieb' anhaftet und daß das Materielle vom Künstlerischen—wohlgemerkt: vom Reproduktivkünstlerischen—nicht immer ganz zu trennen ist. Um so verehrungswürdiger, daß gerade bei der schon rein physisch bewundernswerten Arbeitsleistung, die Strauß, sei es in Berlin und Wien, sei es auf andauernden Reisen, vollbringt und bei all dem dadurch bedingten Umsetzen künstlerischer in Geldwerte, sein Schaffen davon ganz und gar unberührt geblieben ist, rücksichtslos unbekümmert um das, was andre von ihm erwarten, gänzlich abgekehrt vom Verlangen der 'Händler.' Ebenso steht es mit seiner Leistung als Interpret eigener und fremder Werke. Aber immerhin: hier gibt es doch Fälle, in denen er die volle und unantastbare Überzeugung seines künstlerischen Gewissens nicht ganz rein zu erhalten vermochte. Er hat einmal, als er das ‘berüchtigte’ Konzert im New Yorker 'Wannemakers Warenhaus' nach reiflicher Prüfung der befriedigenden, zur Verfügung stehenden künstlerischen Mittel dirigierte, gegen törichte Angriffe dagegen das ruhig stolze Wort 
gesagt: 'Echte Kunst adelt jeden Saal und anständiger Gelderwerb für Weib und Kind schändet niemanden, nicht einmal einen Künstler.' Heute gibt es doch Fälle, in denen er dieses Wort zum mindesten abschwächen müßte; wo er, der auf das eine oder andere Honorar doch leicht verzichten könnte, eine Konzert- oder Theateraufführung abgehalten hat (z. B. in der Schweiz 1917), auch wenn die Vorbedingungen des künstlerischen, oder richtiger gesagt, des Straußschen Niveaus nicht vollständig gegeben waren oder doch im letzten Augenblicke durch Absagen oder durch andere Hemmnisse in solche Weise herabgemindert wurden, daß er sich hätte weigern müssen, den Taktstock zu führen, die Verantwortung für das Ganze zu tragen und es mit seinem Namen zu decken. Daß er es dann manchmal doch tat, sei es aus einem gewissen Leichtsinn der Siegesgewißheit, die dem eigenen Stern vertraut, sei es aus einer gewissen Verachtung gegen das Publikum, schließlich aber doch in einem Anfall mangelnder Ehrfurcht vor dem Kunstwerk, ist ihm, der sonst der sachlichsten aller Künstler ist, doch sehr verdacht worden. (Selbst dann nicht mit Unrecht, wenn die Sache schließlich doch ganz oder halbwegs klappte. Was übrigens nicht immer der Fall war.) Vorfälle dieser Art, die in dem ergiebigen, bereichernden Leben dieses reich schenkenden Künstlers zu den seltenen und ganz vereinzelten gehören, wären kaum der Erwähnung wert, wenn nicht gerade sie, maßlos aufgebauscht und hämisch verallgemeinert, den Hauptanlaß zu der niederträchtigen Fabel von dem zynischen und geldgierigen Strauß gegeben hätten. Aber, daß er, in dem eben erwähnten Sinn, wie in anderem schon vorhin auseinandergesetzten, nicht ganz ohne Anteil an dieser von Gehässigkeit und Dummheit ausgebrüteten Auffassung seines Wesens ist, darf in einer Schilderung wie dieser, die ohne Wahrhaftigkeit wertlos wäre, nicht verschwiegen werden.” Specht I, 89-90.

${ }^{23}$ On post-war German American relations see Jessica G.E. Gienow-Hecht, Music and Emotions in Transatlantic Relations, 1850-1920 (Chicago: University of Chicago Press, 2009); and Joseph Horowitz, Classical Music in America: A History (New York: Norton, 2005), 265-70.

${ }^{24}$ John Francis Hylan (1868-1936), mayor of New York City from 1918-1925.

${ }^{25}$ Franz Strauss (1897-1980), Richard Strauss's only child.

${ }^{26}$ Polish soprano Claire Dux (1885-1967), the first Sophie in Der Rosenkavalier in Berlin (1911) and London (1913), who also performed with Strauss on this North American tour.

${ }^{27}$ Composer Rubin Goldmark (1872-1936), nephew of Hungarian composer Carl Goldmark (1830-1915).

${ }^{28}$ Bavarian-born New York City Chamberlain Philip Berolzheimer (1867-1942).

29 "Mittags 12 Uhr großer Empfang Strauß durch den Bürgermeister der Stadt New York. Es halten ungefähr 15 Automobile vor dem Hotel St. Regis—alle tragen rückwärts das Wappen der Stadt. Im 1. fährt Strauß mit 3 Herren, im 2. Franz mit Begleitung, im 3. ich mit Diamond, im 4. die Dux — weiter kenne ich die Menschen nicht. Die Autos sind links und rechts von Schutzleuten begleitet, die auf Motorrädern fahren und ständig mit einer Sirene pfeifen, das bedeutet, daß wir ohne Aufenthalt alle Straßen kreuzen, alle anderen Wagen stehen still—links und rechts stehen Menschen—alle lasen natürlich von dem Empfang. Strauß fährt durch N.Y. like a king. Vor dem Rathaus wimmelt es von Photographen — wir werden gefilmt und geknipst. Dann treten wir ein in’s Rathaus. In dem Empfangsraum warten schon viel Geladene. Zuerst spricht ein Neffe Goldmarks, dann Mr. Berlitzheim, dann der Mayor. Strauß erhebt sich und erwidert—anfänglich sehr stockend—dann fließend und voll esprit. Er erwidert deutsch und entschuldigt sich, daß er in seiner Muttersprache antwortet. Seine kurze Rede ist aber englisch übersetzt und wird danach gleich vorgelesen, worauf ein großes Applaus einsetzt. Strauß war über die große Ehrung gerührt—er sah ganz blass aus. Es kam dann eine große Vorstellung, wobei die Dux und ich dem Mayor vorgestellt wurden. Danach wieder große Filmerei und Abfahrt zum Hotel, wo Diamond ein Frühstück gab. Abends das ereignisreiche Konzert von Strauß in der Carnegiehall, das einem Triumphe glich—danach saßen wir 3 oben am Zimmer und aßen zur Nacht. Er sagte u.a. 'Es ist schwer Schlüsse zu schreiben. Beethoven und Wagner konnten es. Es können nur die Großen. Ich kann’s auch.'” Schumann, 31 October 1921.

${ }^{30}$ Hermann Bahr (1863-1934), Austrian writer. These exact words of Bahr do not appear to have been published but rather, as Specht stated, were spoken to him.

31 "Ob das Publikum des Meisters Strauß auch das dieses Buches sein wird, weiß ich nicht. Aber ich würde es wünschen; wenn auch nicht, weil dort die Leser anzutreffen sind, nach denen ich verlange. Im Gegenteil. Hermann Bahr hat einmal über dieses Publikum köstliche und leider wahre Worte gesprochen: 'Sage mir, wem du gefällst, und ich sage dir, wer du bist! An seinen Bewundern erkennt man den Künstler. Das trifft fast immer zu. Nur bei Richard Strauß nicht, gar nicht. Was sich zu seinen Premièren drängt, ist der Abhub Europas; man findet da wirklich die schlechteste Gesellschaft beisammen, man sehnt sich nach einem unverhohlenen Taschendieb. Daher sein Weltruhm. Wenn man ihm aber dann in die Augen sieht, kann man es nicht begreifen. Und wenn man gar seine Musik hört, noch weniger. Seine Musik müßte diesen Bewunderern Entsetzten einjagen. Es ist sein Glück, daß sie sie nicht hören. Was sie bewundern und an ihm preisen, ist seine sportliche Leistung.' Das ist ja nur insofern übertrieben, als neben dieser Gesellschaft auch die zehn, zwanzig besten Menschen von Europa da sind, wenn ein 
neues Strauß-Werk aufgeführt wird. Sonst aber ist es nur zu wahr. Der ungeheure Erfolg der Straußchen Musik ist ebenso ein Mißverständnis, wie es—nach des Meisters eigenem schmerzlichen Wort—der der Wagnerschen war. Ich möchte dazu beitragen, daß aus dem Mißverständnis ein Verständnis wird. Daß auch die Snobs, Herr und Frau Überalldabei, die Dummen, die Allerweltsmenschen, die Totalisateure der Kunst sie hören lernen. Wirklich hören; wie sie ist, nicht wie sie ihnen erscheint. Denn dann werden die meisten erschreckt davon gescheucht werden und nur die wenigen unter ihnen, hinter deren Eitelkeit und Neugier doch irgendeine Sehnsucht, ein heimliches Wünschen nach irgendeinem Sinn ihres leeren Lebens schlummern mag—nach jenem Sinn, den die Musik von Richard Strauß, dieser Siegesmarsch des Irdischen, glühend wie keine andere von heute in sich trägt—diese wenigen werden plötzlich erwachen und entdecken, daß sie andere, freiere, zu sich selber mutige Menschen geworden sind.” Specht I, 17.

${ }^{32}$ Violinist Michel Piastro (1891-1970), concertmaster of the San Francisco Symphony (1925-1930) and New York Philharmonic (1931-1943).

${ }^{33}$ Schumann might be referring to Loomis Hammond Taylor (1889-1958), stage manager at the Metropolitan Opera and subsequently director of the Cleveland Grand Opera Company.

${ }^{34}$ Edmund Hellmer (1850-1935) created the Johann Strauss II monument, which had recently been unveiled on 26 June 1921.

35 “ 5 Uhr Ankunft St. Louis—großer Erfolg, gut bei Stimme. Zusammen mit Piastro und seiner reizenden Frau genachtmahlt. Die beiden bleiben hier bis 26. wo wir drei nach Indianapolis reisen. Bin so froh nicht allein hier zu sein, denn Strauß u. Taylor fahren heut Nacht nach C[?]ansas City, wo er Konzert mit der Dux hat. Strauß wollte mich absolut mitnehmen, aber ich will etwas Ruhe haben-10 Std. Eisenbahnfahrt und wieder zurück—nein, lieber hier und wenn ich auch sehr allein bin.” Schumann, 21 November, 1921. "[23 November:] Entzetzliche Einsamkeit. Mit Piastros Nachmittag im Park spazieren—früh schlafen gegangen. [24 November:] Heut Vormittag ganz allein $1 \frac{1}{2}$ Std. im Park. Wunderbar kalter Tag nach dem nächtlichen Gewitter, das mich beben machte.-Ach wenn ich doch täglich sänge und reiste, damit man nicht eine solche Stadt länger als notwendig erleben müßte. Ich vergaß übrigens, daß hier bei Strauß’ Ankunft alle Zeitungen voll waren: 'Der Walzer König ist da.' Und das Denkmal Johann Strauß (Wiener Volksgarten) war abgebildet. Es paßt zu dieser Stadt, aber es ist wenigstens amüsant.” Schumann, 23 and 24 November, 1921.

${ }^{36}$ Specht's characterization of Strauss and his music indulges in Nietzschean tropes, including an emphasis on the Will ("Die durch [Strauss's] Werk zum Menschen gekommen und die ihm selbst näher sind, wissen, welcher Dämon in ihm brennt; wissen, daß sein festes Sichbewahren nicht aus seinem Wesen, sondern aus seinem Willen kommmt...." [Specht I: 88]) and "the South"-Bavaria and beyond ("bajuvarischen Instinkte" [I:48], "Immer fast knabenhaft helle Stimme in ihrer unfeierlichen Gemütlichkeit, den lässigen, unsoignierten Umlauten des süddeutschen Tonfalles” [I: 90], “die spezifisch Straußche Melodik ... aus Schumannschen und Mendelssohnschen Sprachwendungen allmählich befreit und das eigentliche Gepräge ihres lockend sinnlichen, oft ganz italienisch überströmenden und wieder in Funkenstieben schelmischer, bewegter Heiterkeit und Grazie so bestrickenden Heraussingens findet” [I: 33], "wie unter südlicher Sonne gereiften Melodik” [I: 67], “diese Melodik ... sonnenbrauner und heißer ist als die 'klassische deutsche', daß sie aus südlicheren Distrikten kommt” I: 72]). ${ }^{37}$ Specht was no less enthralled by Mahler than he was by Strauss, and he penned two books about the former: a concise (57 pp.) biography Gustav Mahler (Berlin: Gose and Tetzlaff, 1905) and the comprehensive (478 pp.) Gustav Mahler (Berlin and Leipzig: Schuster and Loeffler, 1913). Regarding the latter, Specht's revisionist purpose and tendency toward anectodal reflection is consistent with his Strauss book. Suffice it to say that while Specht viewed Mahler and Strauss as two very different men and composers, he did not argue for one over the other, but rather believed that the music of each was authentic to its creator and epoch.

${ }^{38}$ Feodor Chaliapin (1873-1938), Russian bass; at this time he was returning to the Metropolitan opera after fourteen years.

39 "Wohltätigkeitskonzert für Witwen und Waisen der Seeleute—hatte mit 3 Straußliedern großen Erfolg. Chaliapine sang auch noch—-herrlicher Künstler-leider nicht mehr ganz auf der Höhe. Dann spielte noch eine Geigerin Sonate v. Strauß. Strauß ist so reizend und immer auf meinen Erfolg bedacht. Vor dem Konzert sagte er: 'Halten’s doch die hohen Teen ruhig länger, nicht immer so genau singen.' Nachher fragte ich: 'Na, sang ich die hohen Töne lang genug?' 'Ja,' sagte er lustig, 'aber mit einem gewissen inneren Schamgefühl.' Er meint, weil ich immer nur singe, wie’s dasteht. Über meinen Erfolg strahlte er. Hinterher saßen wir noch gemütlich alle im Rauchsalon.” Schumann, 25 October 1921.

40 "Richard Strauß: die stärkste Kraft, die der Magnetnadel der Musik von heute Richtung gibt; der Gegenpol Max Regers, der sich in alte Formen verliebt und sie mit seiner Musik erfüllt, die eben durch diese Form erst bestimmt wird, während Strauß sich in Ausdrucksmöglichkeiten verliebt, den Gesichten, die seinen Geist bevölkern, ihre 
tönende Erscheinung gibt und durch sie erst Form bestimmen läßt. Der Erlöser von Pathos, von der Deklamation des Adagio um jeden Preis; der Eroberer neuer Territorien der Musik, mit dem Mut zum Äußersten in allen Verwegheiten einer gesteigerten und differenzierten Rhythmik und Harmonik und mit dem Mut zu einer Melodik, deren Quellen oft von Italien nordwärts fließen und die doch, wo ihr schwungvoller Glanz zu süß vibrierender Sentimentalität wird, eine verborgene Herzensschwäche entschleiert, sich lieber selber fast parodistisch in ironisch übertriebenes Schmachten rettet, als eine Weichheit zu verraten, die gerade dieser mannhaft aufrechten, abenteuerfrohen, unerschrockenen und heiter gelassenen Menschlichkeit so wohl ansteht. Der überzeugendste Beweis, daß Gesetz und Regel nicht zur Fessel werden müssen, sondern zu Faktoren organischer Weiterentwicklung, wenn einer kommt, der auch das kann, was er nicht zu wollen braucht, das hundertmal Gesagte verschmähen darf und sich auf die eigene Meisterschaft zu verlassen vermag, die das Unerprobte befestigt, alle Willkür fernhält und allen Inhalt eines guten Heute, alle Träume eines besseren Morgen nahebringt. ... Er gehört zu den ganz wenigen, an denen man nicht ohne Auseinandersetzung vorüber kann; zu denen man sich mit Haß oder Entzücken, mit Abscheu oder Bewunderung stellen mag, aber zu denen man sich eben stellen muß; die nicht zu übergehen sind und die keinen gleichgültig lassen können. Und zu denen, die immer wieder neue Überraschungen bereit haben; die nicht auf ein Gestern festzunageln sind; die man immer dort findet, wo man es am wenigsten erwartet, und die jeder Formel und jeder Registrierung spotten. Das haben sie ihm am meisten übelgenommen: daß er sich niemals um Wünsche und Prophezeiungen, sondern einzig um sein inneres Gebot, um den Zwang der Stunde, um den—oft und oft dem eigenen Verstand trotzenden-Antrieb der befehlshaberischen Stimme gekümmert hat, die ihn zur Produktion aufrief. So war er von jeher und so ist er heute noch immer. Ruht er nach einem Werk aus, so ist's ein Festtag ohne Wende; kein Zielpunkt, nur ein Meilenstein; kurze Wegrast, aber schon mit dem Blick nach neuen Weiten.” Specht I, 21-22.

${ }^{41}$ Marcella Sembrich (1858-1935), coloratura soprano who had enjoyed a lengthy career at the Metropolitan Opera before the First World War, and was a renowned singing teacher based in upstate New York.

42 "Morgens Rückfahrt mit Strauß. Wir sprechen über Stimmen und Studium. Ich frage ihn, ob er meint, daß ich bei der Sembrich was lernen kann. Er verneint und sagt: 'was Ihnen fehlt, kann ich Ihnen sagen, oder Ihr Mann. Sie müssten öfter etwas mehr legato singen und lernen, was z.B. die Stimme nicht hergiebt, mit dem Gesichtsausdruck zu ersetzen. Sie singen oft zu ehrlich—-täuschen Sie doch über die Schwächen hinweg.' Er hat recht.” Schumann, 2 November 1921.

43 “Je öfter man die Straußchen Werke empfängt, desto transparenter werden sie, verlieren alle Schrecken—sogar die 'Elektra' in ihrer duster furchtbaren Größe spricht in grandiosen Stimmen erzener Melodik, wo die Meisten früher bloß zusammenhanglose, aus tosenden Mißklängen geballte Tonkaskaden zu vernehmen meinten; man hat zuerst nur die Geste, nur die betörende Brillanz der Attitude, aber erst später diese Tonsprache selber verstanden, die so durchaus die von heute ist und doch lückenlos an die natürliche Entwicklung der Dinge anknüpfte; und nur manche lernten diese Tonsprache als den höchsten, stärksten, lebenszugewandten, erdenfrohen Ausdruck unseres Selbst und unserer Zeit lieben, im Gegensatz zu Mahlers lebensabgewandter, jenseitssuchender, himmelsfroher Musik, die uns der diesseitgen Welt entrückt, während uns die Straußsche erst recht hineinführt, alle Kräfte, alle Lebensfreude erhöhend. ... Er führt selten in die Tiefen; aber mit prachtvollem Schwung in die Höhen und zur Höhe. Er löst keine Lebensrätsel; aber er stärkt zu solcher Lösung. Im Gegensatz zu mancher Musik, die 'nicht von dieser Welt' ist, ist die seine—fast immer wenigstens—ganz von dieser Welt, ganz diesseits.” Specht I, 27, 70. ${ }^{44}$ Regarding the incompatability of Strauss and Adorno, Richard Wattenbarger concludes that, "what was really at stake were two alternative conceptions of what ought to constitute musical Bildung from the turn of the century on." Wattenbarger, “A 'Very German Process': The Contexts of Adorno's Strauss Critique," $19^{\text {th }}$-Century Music 15, nos. 2-3 (2002): 313-36, quote from p. 333. In any case, Specht's thought regarding Bildung was clearly compatible with that of Strauss.

45 "Pittsburgh fürchterliches Regenwetter—unmöglich einen Schritt aus dem Hause. Entsetzliche Langeweile. Konzert schöner Erfolg—nicht so warm wie Chicago. Strauß sagte: "Sie singen viel zu schön für die Leute." Wiegenlied und Schlechtes Wetter mußten wir wiederholen. Bei der letzten Nummer fehlte bei den Noten "All mein Gedanken.” Strauß sagte: “ich kann’s auswendig.” Er spielt aber ein solches Kauderwelsch, daß ich mich noch immer wundre, nicht in eine andere Tonart gekommen zu sein. Ich war sonst sehr ruhig, auch garnicht müde hinterher—ich habe jetzt das Säuseln raus. Als Zugabe sangen wir "Ständchen”. Nach dem Konzert sofort Schlafwagen, wo ich augenblicklich schreibe — der Zug steht noch, wird gleich abgehen.— “ Schumann, 9 November 1921.

${ }^{46}$ On Wagner's vision for Stilblidungsschule, see Patrick Carnegy, Wagner and the Art of the Theatre (New Haven and London: Yale University Press, 2006), 144. 
47 “Ich habe von dem Dirigenten Strauß fast ausschließlich Interpretationen eigener Werke gehört; nur in wenigen Konzerten der Berliner königlichen Kapelle und der Wiener Philharmoniker, zuletzt im Wiener Operntheater, sind mir durch ihn Tonstücke anderer Meister vermittelt worden, Beethoven, Mozart, Wagner, Bruckner. ... [E]r dirigiert ja, abgeshen von seinen ständigen Konzerten und Opernaufführungen, fast ausschließlich Musik von Richard Strauß. Was nicht nur immer ein Fest neuer Offenbarung und heißglühender lebendiger Stunden bedeutet, sondern entscheidende Wichtigkeit in sich trägt; für die Feststellung des richtigen Vortrages dieser Musik, für das Wegräumen all des Schuttes, den Unfähigkeit und verständnislose Dummheit über diese Werke bis zum Unkenntlichwerden aufgehäuft hat, für die Heranbildung zum rechten Stil der Strauß-Interpretation, der freilich noch in seinen Anfängen liegt und erst dann ganz gewonnen sein wird, bis die Sänger und Instrumentalisten nicht nur die richtigen Noten im richtigen Tempo wiedergeben (was schon viel ist!), sondern bis ihnen der Sinn und Inhalt, die formalen Zusammenhänge aufgegangen sein werden, bis sie die Art der Melodik erkannt haben, während vorläufig die meisten nur mehr oder weniger schwierige Intervalle, aber nicht den Bogenschwung der geschlossenen melodischen Linie empfinden, und bis jede Krampfhaftigkeit und mechanische Unfreiheit von ihnen abgefallen ist. Was Richard Strauß hier in allen größeren deutschen Städten leistet, nicht nur in eigener Sache, sondern als Orchester- und Sängerpädagoge, als Erwecker zu neuen Aufgaben und ebenso zu höchster Gewissenhaftigkeit und Disziplin - diese qualitativ und quantitativ gleich umfangreiche Leistung ist vorhin schon erwähnt worden. Kein Zweifel aber, daß er sich bereit finden ließe, mit ganz der gleichen Energie für alle hochragende Tonkunst einzustehen und ein praeceptor germaniae der Musik zu sein; vorausgesetzt, daß es in der würdigen und hochgemuten Art geschehen könne, die nun einmal zu ihm gehört. Dann wäre Wagners Gedanke der Stilbildungsschule, der damals so schmachvoll an der Teilnahmslosigkeit der Mitlebenden scheiterte, zur Wirklichkeit geworden. Und vielleicht wird jetzt wenigstens ein Teil davon zur Wirklichkeit: wenn Strauß als Leiter der Wiener Oper Kunst zeigt. Es fällt schwer, daran zu glauben, daß auch heute geschehen könnte, was sich zur Schande der musikalischen Generation von damals ereignen konnte: daß wenn Strauß zu solchem Lernen aufruft, wie Wagner einst rief, dieser Ruf eines Meisters, der sich jedem ernstlich Wollenden ohne anderes Entgelt als das der Freude an Arbeit und Fortschritt zum Mentor anbietet, im Leeren verhallen könne. Zu Wagner ist damals keiner als Jünger gekommen. Kaum glaublich, daß es jetzt, nach dreißig Jahren Bayreuth, nicht anders sein sollte. Aber unmöglich ist freilich nichts." Specht I, 97-98.

48 "Morgens 9 Uhr angekommen. Unglückstag. Koffer nicht mitgekommen. Kleid, Schuhe, Strümpfe kaufen müssen, während Manager nach Noten herumjagte. Er bekam nur einen Teil und wir mußten Schubert in’s Programm einfügen. Strauß, wie immer, seelenruhig. Gott sei Dank, denn ich war etwas nervös. Abends trotzdem gut bei Stimme - großer Erfolg. Ich sagte jedes Lied extra an, was dem Publikum besonders gefiel. Schubertlieder: Musensohn, Frühlingstraum, Forelle, Geheimes u. Lied im Grünen. Dann hatten wir verschiedene Straußlieder bekommen, und einige spielte Strauß auswendig. Er ist kein guter by heart player, und es passierte etwas Wunderbares bei “All mein Gedanken”. Schon nach dem 3. Takt wußte er nichts mehr von der Begleitung, und komponierte ein vollständig neues Lied. Ich sprang mit, die Worte paßten absolut, niemand ahnte etwas im Zuschauerraum, und als wir glücklich zu Ende waren, drehte ich meine Augen nach rechts, um zu sehen, wie er reagierte. Da sah ich nur seinen Mund von einem zum anderen Ohre lachen—es war wirklich schwer für mich die Ruhe und den Ernst zum nächsten Liede "Frdl. Vision” zu finden. Nach der Gruppe lachten wir noch immer im Künstlerzimmer, und ich bat ihn das neue "All m. Ged." nachher sofort aufzuschreiben, aber er antwortete "oh, das habe ich schon jetzt total vergessen.” Wie schade! Ich fand es viel schöner als das Original.” Schumann, 7 December 1921. 